\title{
Development of improved soluble inhibitors of FasL and CD40L based on oligomerized receptors
}

\author{
Nils Holler ${ }^{\mathrm{a}}$, Takao Kataoka ${ }^{\mathrm{a}}$, Jean-Luc Bodmer ${ }^{\mathrm{a}}$, Pedro Romero ${ }^{\mathrm{b}}$, \\ Jacqueline Romero $^{\mathrm{a}}$, David Deperthes ${ }^{\mathrm{a}}$, Jürgen Engel $^{\mathrm{c}}$, Jürg Tschopp ${ }^{\mathrm{a}}$, \\ Pascal Schneider ${ }^{\mathrm{a}, *}$ \\ ${ }^{a}$ Institute of Biochemistry, University of Lausanne, Ch. des Boveresses 155, CH-1066 Epalinges, Switzerland \\ ${ }^{\mathrm{b}}$ Division for Clinical Onco-immunology, Ludwig Institute for Cancer Research, CHUV, CH-1011 Lausanne, Switzerland

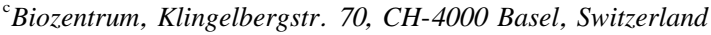

Received 10 August 1999; received in revised form 7 December 1999; accepted 7 December 1999

\begin{abstract}
TNF receptor family members fused to the constant domain of immunoglobulin $G$ have been widely used as immunoadhesins in basic in vitro and in vivo research and in some clinical applications. In this study, we assemble soluble, high avidity chimeric receptors on a pentameric scaffold derived from the coiled-coil domain of cartilage oligomeric matrix protein (COMP). The affinity of Fas and CD40 (but not TNFR-1 and TRAIL-R2) to their ligands is increased by fusion to COMP, when compared to the respective Fc chimeras. In functional assays, Fas:COMP was at least 20-fold more active than Fas:Fc at inhibiting the action of sFasL, and CD40:COMP could block CD40L-mediated proliferation of B cells, whereas CD40:Fc could not. In conclusion, members of the TNF receptor family can display high specificity and excellent avidity for their ligands if they are adequately multimerized. (c) 2000 Elsevier Science B.V. All rights reserved.
\end{abstract}

Keywords: Tumor necrosis factor; FasL; CD40L; TRAIL; Apoptosis; Inhibitor

\section{Introduction}

Ligands of the tumor necrosis factor (TNF) family are synthesized as homotrimeric type II membrane proteins, which fulfill their biological functions

\footnotetext{
Abbreviations: OPG, osteoprotegerin; TNF, tumor necrosis factor; TNFR, TNF receptor; TRAIL, TNF-related apoptosis inducing ligand; CMP, cartilage matrix protein; COMP, cartilage oligomeric matrix protein; CTL, cytotoxic T lymphocyte; PA, Protein A

*Corresponding author. Tel.: +41-21-692-5743; fax: +41-21692-5705.

E-mail address: pascal.schneider@ib.unil.ch (P. Schneider)
}

either in the membrane-bound form and/or as soluble cytokines after proteolytic processing. Their receptors belong to a family of type I membrane proteins characterized by repetitive cysteine-rich modules in their extracellular domains.

Presently, 18 ligands and 22 receptors have been described, some of which are orphans while others have one or more binding partners. Most of the functions executed by these systems are associated with the immune system and are in relation with the control of proliferation, differentiation and apoptosis. For instance, Fas, TNF-R2, CD30 and GITR are involved in the control of T-cell receptor-mediated 
apoptosis of thymocytes and mature T cells (Russell et al., 1993; Zheng et al., 1995; Amakawa et al., 1996; Nocentini et al., 1997). Soluble TNF acts as an inflammatory cytokine coordinating host defenses in response to infection (Vassalli, 1992). TRAIL/Apo$2 \mathrm{~L}$, whose expression can be induced on peripheral blood $\mathrm{T}$ cells or on monocytes by interferons, mediates tumoricidal activity (Griffith et al., 1999; Kayagaki et al., 1999). T-cell help via CD40L/CD40 interaction is important for B cell survival, proliferation, immunoglobulin isotype switch and differentiation (Laman et al., 1996; van Kooten and Banchereau, 1997). Moreover, the CD40 signaling pathway increases dendritic cell function and is therefore implicated in antigen-specific $\mathrm{T}$-cell responses in vivo (Grewal et al., 1995; Campbell et al., 1996).

The activity of TNF-family members can be regulated by soluble receptors, which are either gene products on their own or result from proteolytic processing of membrane-bound receptors. For example, the soluble dimeric receptor OPG favors bone formation by inhibiting RANKL/TRANCE/ODAF, which is both a survival factor for dendritic cells and an inducer of osteoclast differentiation and activation (Anderson et al., 1997; Simonet et al., 1997; Wong et al., 1997; Bucay et al., 1998; Lacey et al., 1998).

Recombinant soluble receptors, which are classically produced as fusion proteins with the dimerizing constant domain of immunoglobulin G, are commonly used as specific inhibitors of their cognate ligands (Chamow and Ashkenazi, 1996). Indeed, high-affinity inhibitors of TNF-family members are potentially useful for treatment of disease where expression of these ligands is disregulated. Chronic inflammation with elevated TNF levels leads to diseases such as Crohn's disease or rheumatoid arthritis, and both conditions can been improved by the administration of TNF-R2:Fc alone or in combination with other treatments (Stack et al., 1997; Weinblatt et al., 1999). Ectopic expression of FasL has been shown to be involved in toxic epidermal necrolysis, a severe, often lethal reaction to drugs that leads to massive keratinocyte cell death. Inhibition of the Fas-FasL system rapidly improves this condition (Viard et al., 1998).

Chimeric receptors have also been used for in vitro studies to analyze the significance of FasL for cytotoxic $\mathrm{T}$ lymphocyte (CTL) function and ac- tivation-induced cell death (Suda et al., 1993; Hanabuchi et al., 1994; Dhein et al., 1995; Ju et al., 1995). Furthermore, in vivo analysis was performed by administration of recombinant RANK:Fc or by transgenic expression of lymphotoxin $\beta$ receptor:Fc (Ettinger et al., 1996; Bachmann et al., 1999).

In the field of cytokine research, the use of chimeric soluble receptors is a promising alternative to monoclonal antibodies to create efficient inhibitors: the simple fusion of receptors to an appropriate oligomerization support yields blocking agents with high specificity and high affinity. Soluble receptors have the potential to block unknown ligands and, when they do bind more than one ligand, display a specificity distinct from that of an antibody.

In this study we demonstrate that the fusion of the extracellular domains of Fas and CD40 to the pentamerization domain of cartilage oligomeric matrix protein (COMP) (Malashkevich et al., 1996; Terskikh et al., 1997) enhances their inhibitory activity towards their respective ligands as compared with classical Fc fusion proteins.

\section{Materials and methods}

\subsection{Materials}

The anti-Flag M2 monoclonal antibody and M2agarose was purchased from Sigma (Buchs, Switzerland). Cell culture reagents were obtained from Life Sciences (Basel, Switzerland). Molecular weight standards for gel permeation chromatography, HiTrap chelating and HiTrap Protein A columns were obtained through Pharmacia (Dübendorf, Switzerland). Goat anti-mouse antibodies coupled to peroxidase or to FITC were purchased from Jackson laboratories (La Roche, Switzerland). Anti-CD19 antibody was obtained through Pharmingen.

\subsection{Cells}

Murine B lymphoma A20 cells were maintained in DMEM containing 5\% FCS and $50 \mu \mathrm{M} \beta$-mercaptoethanol. The human $\mathrm{T}$ lymphoblastoma Jurkat, the Jurkat subclone D 1.1 (kindly provided by Dr J. 
Browning, Biogen, Cambridge, MA), BJAB Burkitt lymphoma, chronic myelogenous leukemia K-562 and the murine fibrosarcoma WEHI-164 cells were cultured in RPMI 1640 supplemented with $10 \%$ FCS. Stable clones of 293 cells were grown in DMEM Nut Mix F-12 supplemented with $2 \%$ FCS. Perforin $^{-1-}$ and gld spleenocytes were grown in RPMI 1640 containing 10\% FCS. All media contained antibiotics (penicillin and streptomycin at 5 $\mu \mathrm{g} / \mathrm{ml}$ each and neomycin at $10 \mu \mathrm{g} / \mathrm{ml}$ ) and FCS was heat-inactivated. Human peripheral blood lymphocytes (PBL) were cultured in DMEM supplemented with $10 \%$ FCS and $10 \mu \mathrm{M} \beta$-mercaptoethanol.

\subsection{Vector constructions and establishment of cell lines expressing the receptor chimeras}

Receptor chimera were constructed in a modified PCR-3 vector (InVitrogen) as a succession of interchangeable modules, in the following order $\left(5^{\prime}\right.$ to $3^{\prime}$ ): (a) A HindIII/SalI module containing the extracellular domain of a receptor preceded by the Kozak sequence GCCACC [hTNF-R1, aa 1-211; h-TRAIL-R1, aa 1-239; hTRAIL-R2, aa 1-212; hTRAIL-R3, aa 1-240; hCD40, aa 1-193] or by 24 nucleotides of the $5^{\prime}$-untranslated region [hFas, aa 1-170]; (b) a 14 amino acid linker sequence (PQPQPKPQPKPEPE) in a SalI/XhoI cassette (Terskikh et al., 1997); (c) an oligomerization domain in a XhoI/NotI module [OPG, aa 187-401, referred to as $\delta \mathrm{N}-\mathrm{OPG}$; CMP, aa 451-493 (GenBank 115555); COMP, aa 32-75 (GenBank 1705995)]; (d) a NotI/ $X b a \mathrm{I}$ cassette containing a combined $\mathrm{His}_{6}$-myc tag and a stop codon. The COMP oligomerization domain was flanked by aa sequences GGCC and ARTPGGGS at the $\mathrm{N}$ and C-termini, respectively. The linker was present in all constructs and expression in the absence of the linker has not been tested. For Fc constructs, the hinge, $\mathrm{CH} 2$ and $\mathrm{CH} 3$ domains and the stop codon of hIgG1 were cloned as a SalI/NotI cassette as previously described (Schneider et al., 1997; Schneider et al., 1998). Stable HEK-293 derived cell lines for the production of the recombinant proteins were established by selection in $800 \mu \mathrm{g} / \mathrm{ml}$ of G418 with previously published methods (Schneider et al., 1997).

\subsection{Transient transfection}

$293 \mathrm{~T}$ cells were transfected by the $\mathrm{CaCl}_{2}$ method with previously published methods (Schneider et al., 1997), washed with PBS and incubated for 3 days in serum-free Optimem medium. Supernatants were concentrated 30 times and kept frozen until use. Concentrations of Fas: $\mathrm{N}-\mathrm{OPG}$ and Fas:CMP in concentrated Optimem medium were determined by titration on Western blots using purified Fas:COMP as a standard.

\subsection{Purification of recombinant proteins}

Supernatants of stably transfected 293 cells were loaded onto M2-agarose (ligands) or Protein ASepharose (Fc fusion proteins), washed with PBS and eluted with $50 \mathrm{mM}$ citrate- $\mathrm{NaOH} \mathrm{pH} 2.5$. The eluate was neutralized with Tris- $\mathrm{HCl} \mathrm{pH} 8$ and the buffer was exchanged to PBS in Centrikon-30 concentrators (Amicon, Easton, TX). COMP and CMP chimeras were purified on HiTrap chelating columns. For this purpose, supernatants of stably transfected 293 cells were supplemented with $500 \mathrm{mM} \mathrm{NaCl}$ and $10 \mathrm{mM}$ imidazole and were passed through the columns preloaded with $0.1 \mathrm{M} \mathrm{ZnSO}_{4} \mathrm{pH} 2.5$ and equilibrated in PBS. The column was washed with PBS and proteins were eluted with PBS containing $50 \mathrm{mM}$ EDTA. The buffer was exchanged to PBS as described above. Flag-FasL and Flag-TRAIL were produced as described previously (Schneider et al., 1997; Thome et al., 1997). Flag-CD40L (aa 116261) was expressed in bacteria and purified on M2agarose as described for Flag-TRAIL. Protein concentration was determined by the bicinchoninic acid method (Pierce Chemical, Rockford, IL) using bovine serum albumin as standard and the purity was assessed by SDS-PAGE and Coomassie blue staining.

\subsection{Gel permeation chromatography}

The indicated amount of recombinant protein was loaded in a total volume of $200 \mu$ l onto a Superdex 200 HR 10/30 column (Pharmacia) and eluted at 0.5 $\mathrm{ml} / \mathrm{min}$ in PBS with online recording of absorbance at $280 \mathrm{~nm}$. Fractions $(0.25 \mathrm{ml})$ were analyzed in cytotoxic assays as described below. For the estima- 
tion of the molecular weight, the column was calibrated with the standard proteins thyroglobulin $(669 \mathrm{kD})$, ferritin $(440 \mathrm{kD})$, catalase $(262 \mathrm{kD})$, aldolase $(158 \mathrm{kD})$, bovine serum albumin $(67 \mathrm{kD})$, chicken ovalbumin (43 kD), chymotrypsinogen A $(25 \mathrm{kD})$ and ribonuclease A $(13.7 \mathrm{kD})$.

\subsection{Competition ELISA}

Ninety-six-well ELISA plates were coated with the receptor:Fc chimeras $(0.2 \mu \mathrm{g} / \mathrm{ml}$ in PBS, $100 \mu \mathrm{l}$, $16 \mathrm{~h}, 25^{\circ} \mathrm{C}$ ). The wells were saturated for $1 \mathrm{~h}$ at $37^{\circ} \mathrm{C}$ in PBS containing 5\% fetal calf serum (blocking buffer). When sCD40L was used, blocking buffer was PBS containing $4 \%$ fat-free milk and $0.05 \%$ Tween-20. Competing Fc or COMP fusion proteins were serially diluted in $100 \mu \mathrm{l}$ of blocking buffer in the presence or absence of $1 \mu \mathrm{g} / \mathrm{ml}$ of Protein A. Ligands were added at constant concentration (sFasL: $2 \mu \mathrm{g} / \mathrm{ml}, 36 \mathrm{nM}$, sTNF $\alpha$ : $0.02 \mu \mathrm{g} / \mathrm{ml}, 0.36$ nM, sTRAIL: $0.1 \mu \mathrm{g} / \mathrm{ml}, 1.4 \mathrm{nM}$, sCD40L: 0.5 $\mu \mathrm{g} / \mathrm{ml}, 9.2 \mathrm{nM}$; all in blocking buffer) and allowed to bind for $1 \mathrm{~h}$ at $37^{\circ} \mathrm{C}$. Bound ligands were revealed with $\mathrm{M} 2$ anti-Flag antibody $(1 \mu \mathrm{g} / \mathrm{ml}$ in blocking buffer, $\left.100 \mu \mathrm{l}, 45 \mathrm{~min}, 37^{\circ} \mathrm{C}\right)$, goat anti-mouse antibody coupled to peroxidase (1:2000 in blocking buffer, $100 \mu \mathrm{l}, 30 \mathrm{~min}, 37^{\circ} \mathrm{C}$ ) and $o$-phenylenediamine hydrochloride $(0.3 \mathrm{mg} / \mathrm{ml}$ in $50 \mathrm{mM}$ citric acid, $100 \mathrm{mM} \mathrm{Na} \mathrm{HPO}_{4}, 0.01 \% \mathrm{H}_{2} \mathrm{O}_{2}$ ). Absorbance was measured at $490 \mathrm{~nm}$.

\subsection{Cytotoxic assays}

The cytotoxic assays were performed in 96-well plates in a volume of $100 \mu$ l essentially as described previously (Schneider et al., 1997). Chimeric receptors were serially diluted in medium containing the amounts of cytotoxic ligands able to induce more than $95 \%$ of cell death, as indicated in the figure legends. Where stated, Protein A was present at 1 $\mu \mathrm{g} / \mathrm{ml}$. sFasL was always used in the presence of 1 $\mu \mathrm{g} / \mathrm{ml}$ of $\mathrm{M} 2$ and sTRAIL in the presence of 2 $\mu \mathrm{g} / \mathrm{ml}$ of $\mathrm{M} 2$. No M2 was added in assays with sTNF $\alpha$. Cell were added for a $16 \mathrm{~h}$ incubation and their viabilities were determined using the PMS/ MTS (phenazine methosulfate/3-[4,5-dimethylthiazol-2-yl]-5-[3-carboxymethoxyphenyl]-2-[4-sulfophenyl]-2H-tetrazolium, inner salt) (Promega,
Madison, WI) assay. Absorbance was measured at $490 \mathrm{~nm}$. To express molar concentrations of the various recombinant proteins, $M_{\mathrm{r}}$ was estimated as follows: [(theoretical $M_{\mathrm{r}}+3 \mathrm{kDa}$ per predicted $N$ linked glyan) $\times$ multiplicity]. Fas:Fc, :COMP, :CMP, :SN-OPG: 98, 172, 100 and $105 \mathrm{kDa}$ respectively.

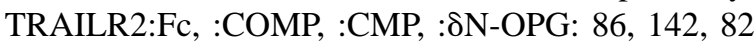
and $93 \mathrm{kDa}$. TNFR1:Fc, :COMP: 104 and $187 \mathrm{kDa}$. CD40:Fc, :COMP: 101 and $180 \mathrm{kDa}$. TRAILR2:Fc: 86 kDa. TRAILR3:Fc: 127 kDa. Flag-TRAIL, FlagFasL, Flag-TNF $\alpha$, Flag-CD40L: 71, 55, 56 and 54 $\mathrm{kDa}$ respectively.

\subsection{BIAcore measurements}

BIAcore measurements were carried out on CM5 carboxymethyldextran modified sensor chips (BIAcore AB, Uppsala, Sweden) at a flow-rate of 5 $\mu \mathrm{l} / \mathrm{min}$. The CM5 chips were activated with a $50-\mu \mathrm{l}$ pulse of a 1:1 mixture of $N$-ethyl- $N^{\prime}$ (3-dimethylaminopropyl)carbodiimide: $N$-hydroxy-

succinimide. Six $\mu \mathrm{l}$ of a $100 \mu \mathrm{g} / \mathrm{ml}$ solution of M2 anti-Flag monoclonal antibody in $10 \mathrm{mM} \mathrm{NaHCO}$ pH 5.5 was then passed over the activated surface. A $50-\mu \mathrm{l}$ pulse of $1 \mathrm{M}$ ethanolamine- $\mathrm{HCl}$ deactivated the remaining $N$-hydroxysuccinimide esters. The amount of M2 immobilized using this procedure was around 4600 response units. To analyze FasL-Fas:chimeras and TRAIL-TRAIL-R2:chimeras interaction, a constant amount of flagged ligand was immobilized on the M2-modified surface. To achieve this, a $7-\mu l$ pulse of $2.5 \mu \mathrm{g} / \mathrm{ml}$ Flag-FasL or FlagTRAIL was applied to the surface. This resulted in binding of around 100 to 150 response units (these conditions allowed minimum dissociation of ligands from the M2 surface, while allowing sufficient subsequent receptor binding for the analysis). Binding of the receptor chimera was then analyzed by $15-\mu l$ injections of purified receptor chimeras at concentrations ranging between 1 and $100 \mu \mathrm{g} / \mathrm{ml}$, corresponding to 100-150 response units. Association kinetics were measured for $3 \mathrm{~min}$ and dissociation kinetics for 3 to $5 \mathrm{~min}$. The surface was regenerated to a plain $\mathrm{M} 2$ surface by a $5-\mu$ l pulse of $50 \mathrm{mM}$ citrate- $\mathrm{HCl}, \mathrm{pH} 2.5$. Up to 30 successive rounds of binding and regeneration could be achieved without significantly altering the binding properties of the immobilized M2 antibody. The 
dissociation and association kinetics were analyzed using the manufacturers kinetic analysis program, using the $\mathrm{AB}=\mathrm{A}+\mathrm{B}$ and $\mathrm{A}+\mathrm{B}=\mathrm{AB}$ models respectively. It is noteworthy that the experimental setup used (capture antibody) imposes a limit to the measure of very high affinities.

\subsection{Culture of primary mouse hepatocytes}

C57BL/ 6 mice were sacrificed by cervical dislocation, the liver lobe located above the biliary vesicle was immediately removed and kept in hepatocyte attachment medium (HAM). The lobe was first perfused with $16 \mathrm{ml}$ of $10 \mathrm{mM}$ Hepes $\mathrm{pH} 7.6$ (Hepes) to remove erythrocytes and then with $12 \mathrm{ml}$ of $0.5 \mathrm{mg} / \mathrm{ml}$ collagenase $\mathrm{H}$ (Boehringer Mannheim) in Hepes, $4 \mathrm{mM} \mathrm{CaCl}{ }_{2}$, and then homogenized in a Petri dish in Hepes. The cells were washed in Hepes, then centrifuged $(100 \times g, 30 \mathrm{~s}$, no brake) and resuspended in 60\% isotonic Percoll (Pharmacia) in HAM and again centrifuged $(700 \times g, 2 \mathrm{~min}$, no brake). All buffers and medium were used at $37^{\circ} \mathrm{C}$. Sedimented cells were resuspended in HAM, counted, seeded in flat-bottomed microtiter plates (10 000 per well, $200 \mu \mathrm{l}$ ) and allowed to attach for $24 \mathrm{~h}$. The experimental mixture (serially diluted inhibitors, sFasL (final concentration: $400 \mathrm{ng} / \mathrm{ml}, 7$ $\mathrm{nM}$ ) and $\mathrm{M} 2$ antibody (final concentration: $1 \mu \mathrm{g} /$ $\mathrm{ml})$ ) was added and cells were incubated for another $16 \mathrm{~h}$. The supernatant was taken off, fresh HAM $(100 \mu \mathrm{l})$ was added and the viability assay PMS/ MTS was performed as described under cytotoxic assays.

\subsection{Activation-induced cell death}

Flat-bottom microtiter plates were coated with anti-human CD3 TR66 $(10 \mu \mathrm{g} / \mathrm{ml})$ in PBS for $3 \mathrm{~h}$ at $37^{\circ} \mathrm{C}$. Plates were washed twice with PBS and once with RPMI 1640 medium. Jurkat cells $\left(5 \times 10^{5}\right.$ cells per $\mathrm{ml}, 100 \mu \mathrm{l}$ ) were mixed with the inhibitors as indicated in the figure legend and distributed to each well, then centrifuged $(200 \times g, 3 \mathrm{~min})$ and incubated for $24 \mathrm{~h}$ at $37^{\circ} \mathrm{C}$. Cell viability (OD490) was measured as described for cytotoxic assays. Specific cell protection (\%) was calculated as follows: [(anti$\mathrm{CD} 3+$ inhibitor $)-($ anti $-\mathrm{CD} 3)] /$ [(control) $-($ anti CD3) $\times 100$.

\subsection{Mixed lymphocyte culture}

Animal care was in accordance with institutional guidelines. Responder spleen cells from perforindeficient or gld C57BL/6 mice $\left(\mathrm{H}-2^{\mathrm{b}}\right)$ were cultured with gamma-irradiated (36 Gy) spleen cells from Balb/c mice $\left(\mathrm{H}-2^{\mathrm{d}}\right)$ for 5 days. Before use, nonviable cells were removed from samples by a gradient centrifugation on Ficoll-Paque (Pharmacia Biotech). The labeling was performed with previously published methods (Kataoka et al., 1998). Briefly, target cells (A20) were labeled with sodium $\left[{ }^{51} \mathrm{Cr}\right]$-chromate (Dupont, Boston, MA) for $1 \mathrm{~h}$, then washed three times with RPMI 1640. MLC cells were mixed with target cells $\left(10^{4}\right.$ cells/well $)$ in U-bottomed microtiter plates in the presence or absence of Fas: $\mathrm{Fc}$ and Fas:COMP at $40 \mu \mathrm{g} / \mathrm{ml}$ in a final volume of 200 $\mu l$, and the plates were centrifuged $(200 \times g, 3 \mathrm{~min})$. After incubating for $4 \mathrm{~h}$, supernatants were removed and their radioactivity measured. Specific $\left[{ }^{51} \mathrm{Cr}\right]$ release (\%) was calculated using the following formula: [(experimental release-spontaneous release)/(maximum release-spontaneous release)] $\times$ 100.

\subsection{FACS staining}

The $\mathrm{CD} 40 \mathrm{~L}^{+}$Jurkat clone D $1.1\left(5 \times 10^{5}\right.$ cells $)$ was incubated with $2 \mu \mathrm{g}$ of CD40:COMP in FACS buffer (PBS, $10 \%$ fetal calf serum and $0.02 \% \mathrm{NaN}_{3}$ ). Fas:COMP was used as a negative control. Receptor:COMP were detected with $1 \mu \mathrm{g}$ of $9 \mathrm{E} 10$ anti-myc antibody followed by FITC-labeled goat anti-mouse antibody (1:100). Incubations were performed for $20 \mathrm{~min}$ at $4^{\circ} \mathrm{C}$ in $50 \mu \mathrm{l}$ of FACS buffer.

\subsection{B-cell proliferation assay}

$\mathrm{CD} 19^{+}$cells were purified from human peripheral blood lymphocytes (PBL) with magnetic beads and the remaining $\mathrm{CD} 19^{-}$cells were irradiated $(3000$ rads). $10^{5}$ purified $\mathrm{CD} 19^{+}$cells were mixed with $10^{5}$ $\mathrm{CD}^{-} 9^{-}$autologous irradiated PBL in $120 \mu \mathrm{l}$ of medium containing sCD40L at $100 \mathrm{ng} / \mathrm{ml}(1.8 \mathrm{nM})$ M2 antibody at $10 \mu \mathrm{g} / \mathrm{ml}$ plus or minus Protein A at $1 \mu \mathrm{g} / \mathrm{ml}$ and the indicated concentrations of CD40:Fc or CD40:COMP. Cells were then cultured for $72 \mathrm{~h}$ in 96-well plates, pulsed for $6 \mathrm{~h}$ with 
$\left[{ }^{3} \mathrm{H}\right]$ thymidine $(1 \mu \mathrm{Ci} /$ well $)$ and harvested. $\left[{ }^{3} \mathrm{H}\right]$ thymidine incorporation was monitored by liquid scintillation counting.

\section{Results}

\subsection{Aggregation of chimeric Fas:Fc receptor increases its specific activity}

Chimeric proteins consisting of the extracellular domains of a receptor fused to the Fc portion of an $\mathrm{IgG}$ (receptor:Fc) have been widely used as inhibitory agents to investigate receptor-ligand interactions. We examined the homogeneity in size of purified Fas:Fc by size exclusion chromatography and found that it eluted as a single peak with the expected retention time (Fig. 1a, upper panel). Fas:Fc-containing fractions were able to partially protect A20 cells exposed to a lethal dose of soluble
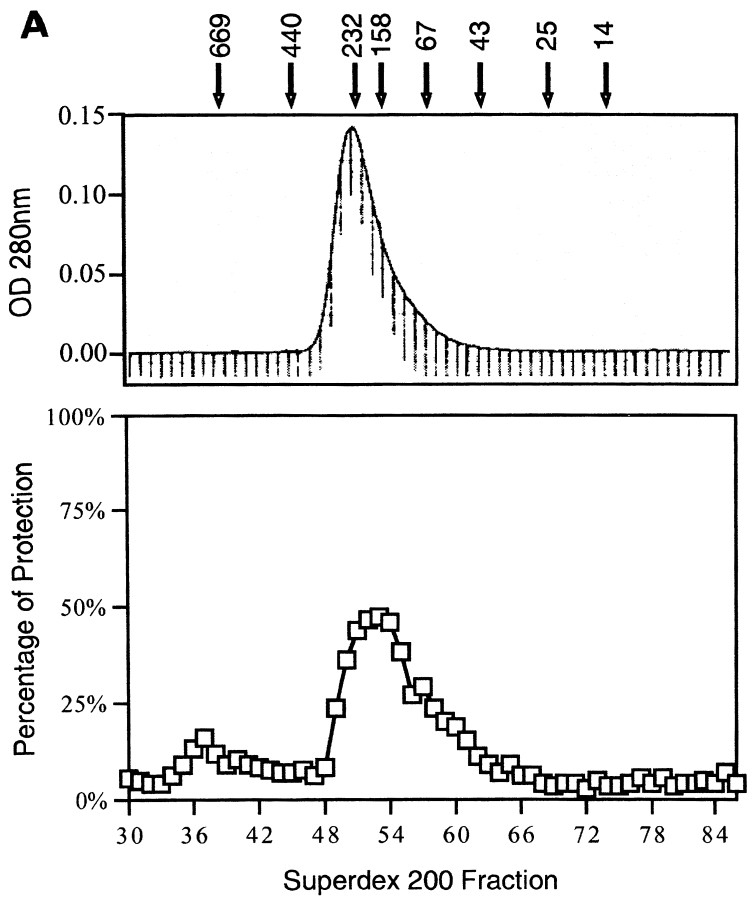

FasL (sFasL), although the level of protection (up to $50 \%$ ) was extremely low considering that the estimated molar ratio of Fas:Fc to FasL was as high as 1000 in the assay (Fig. 1a, lower panel). A weak protecting activity was observed in some of the early fractions of the elution, which was probably due to minute, undetectable amounts of high molecular weight complexes of Fas:Fc. This latter observation suggested that aggregates of the fusion protein could be potent inhibitors of FasL-induced cell death, and we therefore attempted to increase this high molecular weight fraction by aggregating Fas:Fc with the immunoglobulin cross-linking agent Protein A. When the analysis was repeated under conditions where about $10 \%$ of the injected Fas:Fc was shifted to the early eluting fractions (Fig. 1b, upper panel), it was clear that the high molecular weight $\mathrm{Fas}: \mathrm{Fc}$ was an efficient antagonist of FasL cytotoxicity, whereas the remaining Fas:Fc that still eluted as a dimer only conferred partial protection to cells despite its ten-
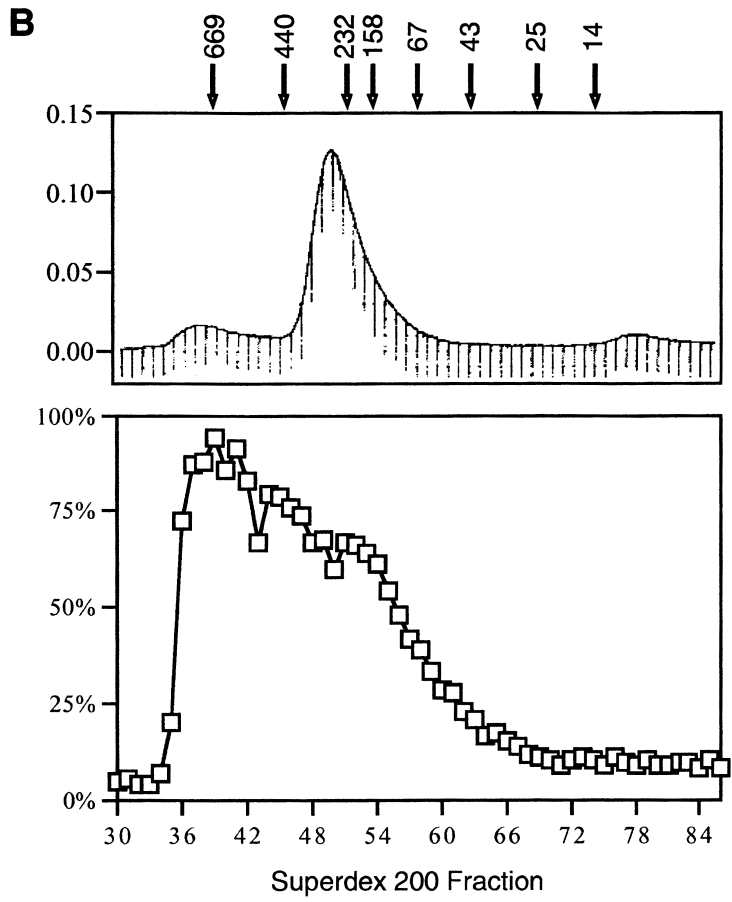

Fig. 1. Aggregation of Fas:Fc potentiates its inhibitory activity. Panel A (upper half): Superdex-200 elution profile of purified Fas:Fc (100 $\mu \mathrm{g}$ ) monitored at $280 \mathrm{~nm}$. The elution position of molecular weight standards are indicated (in kDa). Panel A (lower half): Protection assay against FasL-induced cell death of A20 cells. Aliquots $(10 \mu \mathrm{l})$ of each $250-\mu 1$ fraction were transferred to A20 cells treated with $100 \mu 1$ of sFasL at $0.18 \mathrm{nM}$. Panel B: Same as panel A, except that $100 \mu \mathrm{g}$ of Fas:Fc and $10 \mu \mathrm{g}$ of Protein A were simultaneously loaded on the Superdex-200 column. 
fold higher concentration (Fig. 1b, lower panel). Taken together, these results indicate that the formation of Fas:Fc aggregates substantially increases its specific activity.

\subsection{Construction of novel oligomeric chimeras of TNF receptor family members}

We reasoned that an increase in the oligomerization status of Fas should result in a better avidity towards FasL and thus possibly improve its inhibitory properties. Therefore, we constructed fusion proteins in which the extracellular domains of Fas, TRAIL-R1，TRAIL-R2，TRAIL-R3，TNF-R1 and CD40 were fused via a 14 amino acid linker to the oligomerizing domains of either the cartilage oligomeric matrix protein (receptor:COMP) or the cartilage matrix protein (receptor:CMP). These cartilage matrix proteins have been shown previously to form pentameric and trimeric coiled-coil structures, respectively (Hauser and Paulsson, 1994; Malashkevich et al., 1996; Wiltscheck et al., 1997). The novel fusion proteins, as well as receptor:Fc controls, were expressed in mammalian cells and purified by affinity on metal-chelating columns or on Protein-A (Figs. 2, 3a and b). Fas and TRAIL-R2 were also joined to the C-terminal dimerization domain of the TNF family member osteoprotegerin (Receptor: $\mathrm{NN}$ OPG) (Yamaguchi et al., 1998).

Receptors fused to COMP or CMP clearly oligomerized, as indicated by their slow migration in polyacrylamide gels under non-reducing conditions (Fig. 3b). Fas:COMP and TRAIL-R2:CMP eluted as defined peaks with apparent molecular masses of approximately 400 and $170 \mathrm{kDa}$ by gel permeation chromatography, which are compatible with pentameric and trimeric structures, respectively (Figs. 3c and d). Therefore, we can conclude that the aggregation properties of the coiled-coil oligomerization domains are not impaired by fusion to members of the TNF receptor family.

\subsection{Fas:COMP is a more efficient competitive inhibitor of SFasL than Fas:Fc and has a lower dissociation constant}

Fas:COMP displayed a lower $K_{\mathrm{D}}$ than Fas:Fc when the chimeras were allowed to compete for

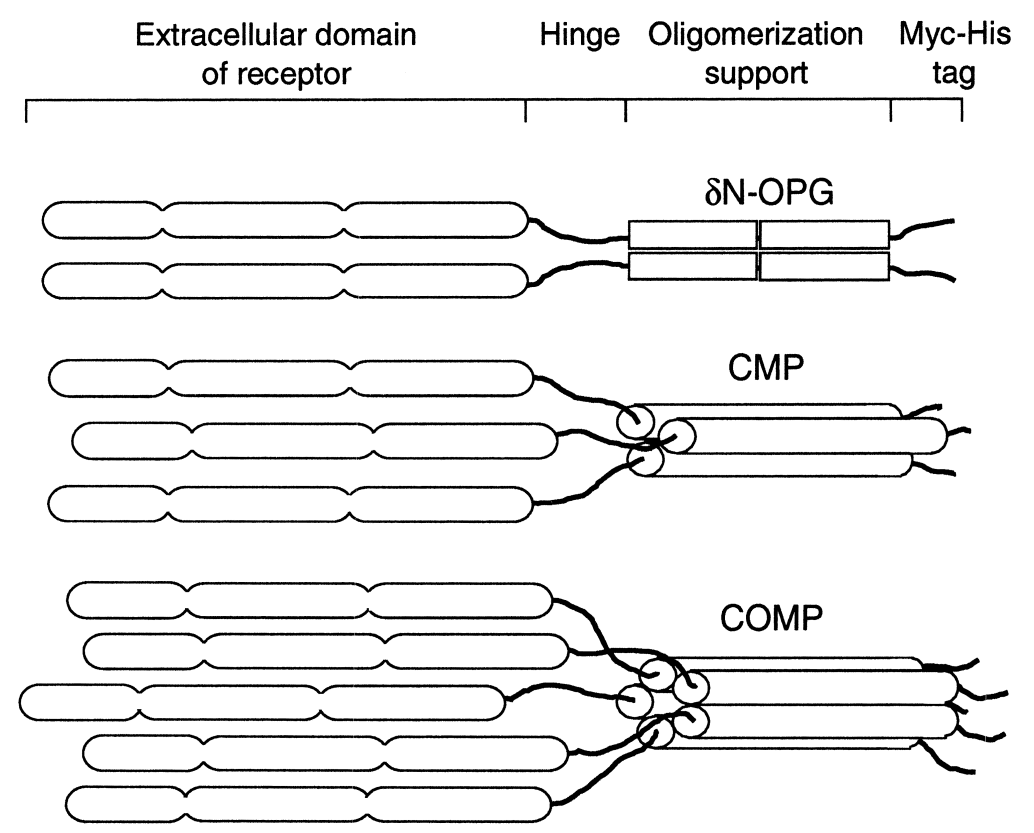

Fig. 2. Schematic representation of the oligomerized soluble receptors described in this study. Soluble receptors were dimerized, trimerized or pentamerized by fusion with the C-terminal domain of OPG, the coiled-coil domain of CMP and the coiled-coil domain of COMP, respectively. 
A

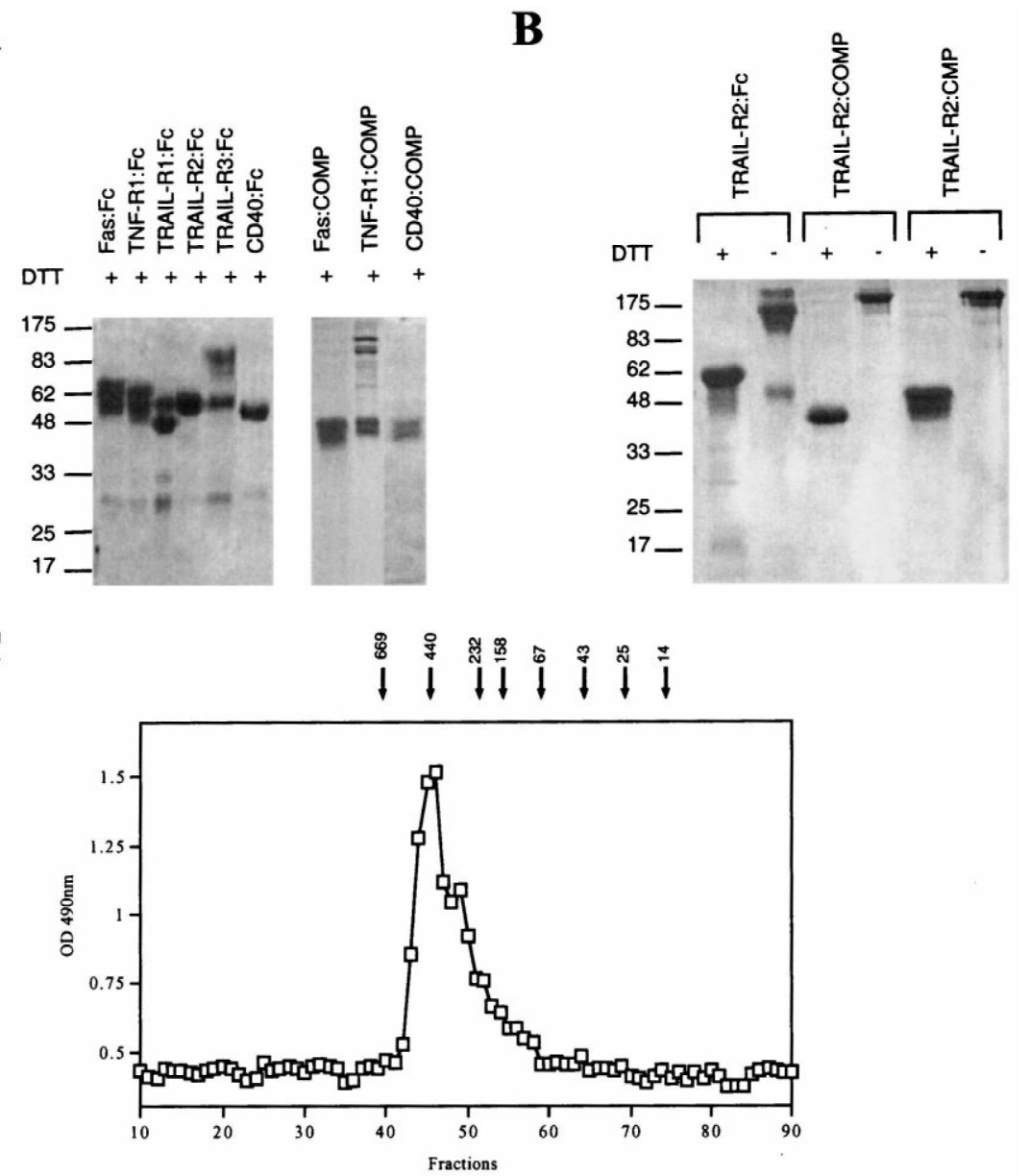

D

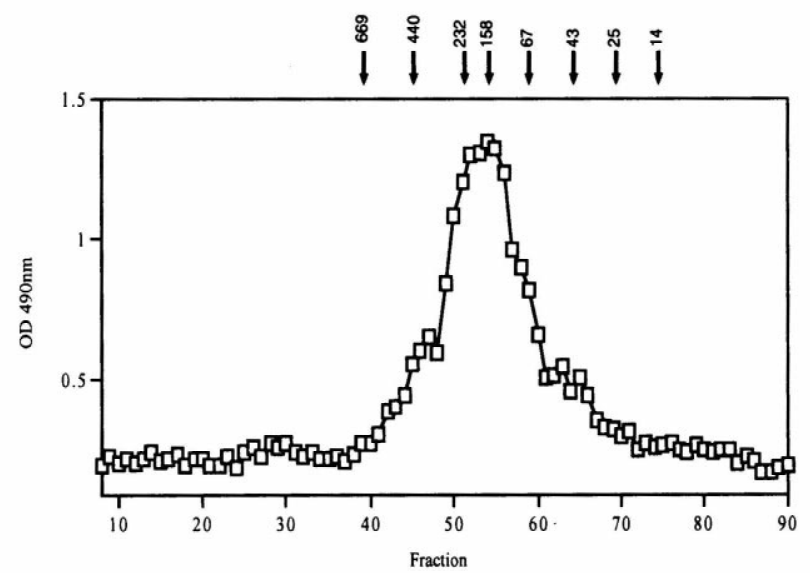

Fig. 3. Characterization of chimeric receptors. Panels A and B: Coomassie Blue staining of various chimeric receptors $(8 \mu \mathrm{g})$ under reducing $(+)$ or non-reducing $(-)$ conditions. Panel C: Size exclusion chromatography of Fas:COMP (50 $\mu$ g). Protection assay against sFasL-induced cell death was performed on A20 cells as described in the legend to Fig. 1. Panel D: Size exclusion chromatography of TRAIL-R2:CMP $(50 \mu \mathrm{g})$. Protection assay against TRAIL-mediated cell death was performed on Jurkat cells treated with $1.4 \mathrm{nM}$ of STRAIL. 
sFasL binding to coated Fas:Fc (Fig. 4a). In accordance with this result, we measured a dissociation constant of $0.77 \mathrm{nM}$ for the sFasL-Fas:COMP interaction, which is around eight to nine times lower than that found for Fas:Fc (Table 1). On the majority of the cell lines tested, the inhibitory activity of Fas:COMP was approximately ten- to 20-fold higher than that of dimeric Fas:Fc, whereas that of Fas:Fc aggregated in the presence of Protein A (Fas:Fc/PA) was intermediate (Fig. 4b, 4e and data not shown). Two cell lines (the murine A20 B lymphoma and the human BJAB Burkitt lymphoma), although efficiently protected by Fas:COMP, were not or only very inefficiently protected by Fas:Fc (Fig. 4c), even in the presence of a 20-fold excess of an irrelevant receptor:Fc (Fig. 4d).

As expected, the activity of the dimeric Fas: $\partial \mathrm{N}$ OPG was similar to that of Fas:Fc (Fig. 4e). Trimeric Fas:CMP inhibited sFasL-mediated lysis as efficiently as Fas:Fc/PA but was about five times less effective than Fas:COMP (Fig. 4e). The inhibitory activity of Fas:COMP was as good or better than that of FasL-blocking mAb Nok-1, 4H9 and 4A5 (Kayagaki et al., 1995; Tanaka et al., 1996).

The superior inhibitory activity of Fas:COMP compared to Fas:Fc was also evident on primary mouse hepatocytes (Fig. 4g) or in a model system for activation-induced cell death using anti-CD3 activated Jurkat cells (Fig. 4h). In all experiments, Fas:Fc/PA yielded an intermediate level of protection. We next tested whether Fas:COMP would inhibit FasL expressed by CTLs. Killing of A20 cells in a 4-h assay depends uniquely on perforin and FasL-dependent pathways, as CTLs deficient for both perforin and FasL have no effect on these cells (Braun et al., 1996). As expected, A20 cells were killed by both perforin-deficient CTLs and FasLdeficient CTLs (Fig. 4i). Fas:Fc and Fas:COMP specifically conferred some protection to cells exposed to perforin-deficient CTLs (Fig. 4i). Surprisingly, there was no difference between Fas:Fc and Fas:COMP and both inhibitors were partially active only when utilized at relatively high concentrations.

\subsection{CD40:COMP is a potent inhibitor of CD4OL}

When the affinities of sCD40L to CD40:Fc, $\mathrm{CD} 40: \mathrm{Fc} / \mathrm{PA}$ or CD40:COMP were compared by competition ELISA, an important increase in affinity (30 fold) was observed for the pentamerized receptor, whereas the effect was intermediate for CD40:Fc/PA (eight fold) (Fig. 5a). We next wondered whether CD40:COMP could also recognize membrane-bound CD40L. To this purpose, we used the Jurkat-derived cell line D1.1 that constitutively expresses surface CD40L, to perform FACS staining analysis using CD40 chimera as a probe. A significant staining was observed with CD40:COMP indicating that CD40:COMP was indeed able to bind to native, unprocessed CD40L (Fig. 5b). To test the activity of the CD40 chimeras in a biological system, we attempted to inhibit the CD40L-dependent proliferation of human $\mathrm{B}$ cells costimulated with anti-B cell receptor. Neither CD40:Fc nor CD40:Fc/PA could significantly prevent proliferation, even when they were administered at high doses. In contrast, CD40:COMP efficiently blocked proliferation, already at relatively low doses (Fig. 5c).

\subsection{Increased affinity of soluble chimeric receptors of the TNF-receptor family is not a general phenomenon}

When the binding of the TRAIL-R2:Fc and TRAIL-R2:COMP to sTRAIL was compared in the competition ELISA assay, no significant differences in the affinities could be observed (Fig. 6a). In addition, the dissociation constants of the interactions of TRAIL with TRAIL-R2:COMP or TRAIL$\mathrm{R} 2: \mathrm{Fc}$ were not significantly different (Table 1). These results are confirmed in a TRAIL inhibition assay on various cell lines, where all TRAILR2:chimeras were equally efficient (Fig. $6 \mathrm{~b}$ and c). The same conclusion was obtained with TRAIL-R1, TRAIL-R3 and OPG, because their inhibitory activities could not be increased upon aggregation with PA (Fig. 6d and data not shown). We also tested the efficiency of various TNF-R1 chimeric proteins at competing with TNF $\alpha$ binding to coated TNF-R1:Fc and at inhibiting the cytotoxic effect of sTNF $\alpha$. No differences were observed between TNF-R1:Fc, TNF-R1:Fc/PA and TNF-R1:COMP (Fig. 6e and f). These results indicate that increased oligomerization is beneficial for the activity of some but not all members of the TNF receptor family. 

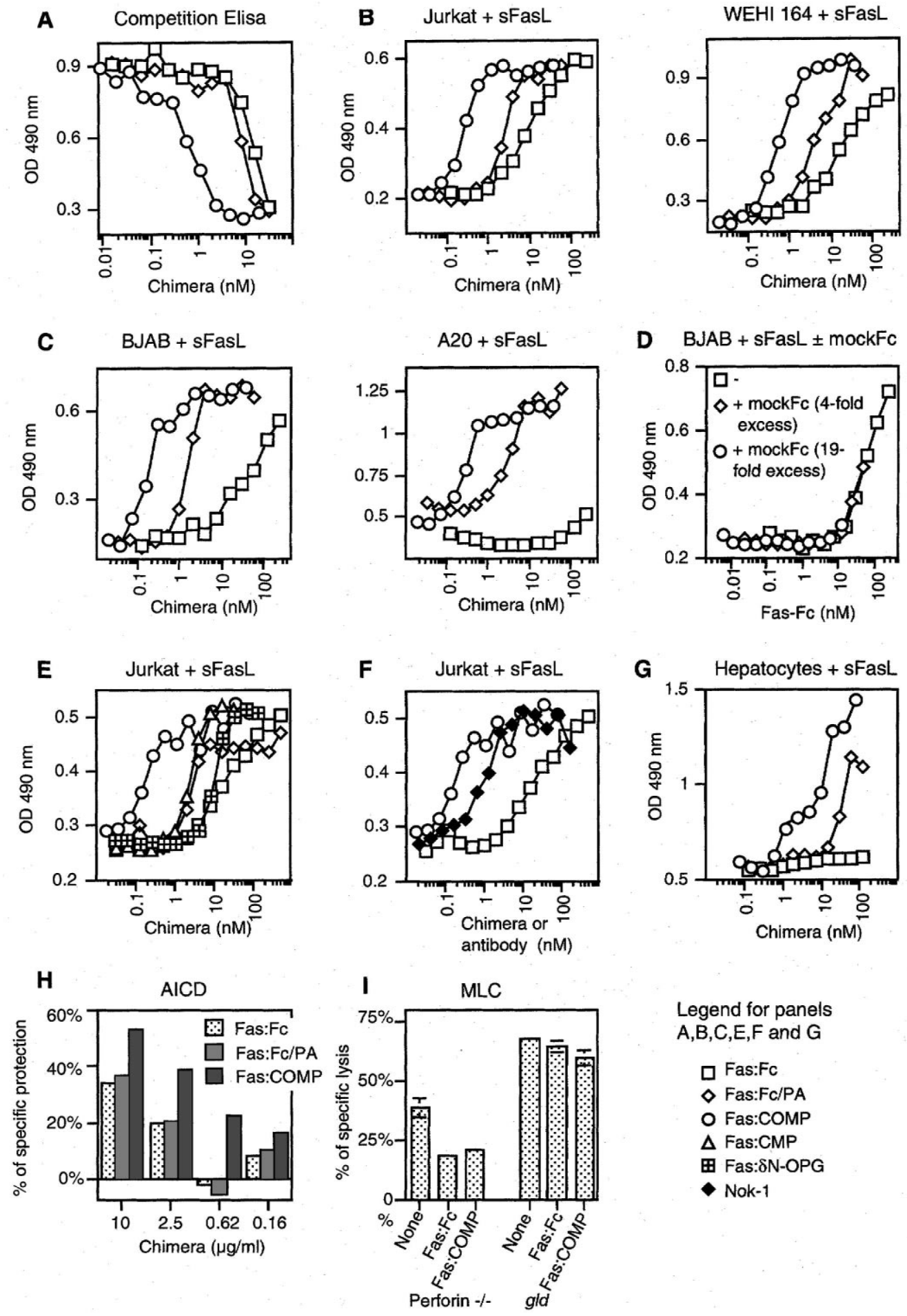

Legend for panels $A, B, C, E, F$ and $G$

$\square$ Fas:Fc

$\diamond \mathrm{Fas}: \mathrm{Fc} / \mathrm{PA}$

O Fas:COMP

$\triangle$ Fas:CMP

田 Fas: $\delta \mathrm{N}-\mathrm{OPG}$

$\bullet$ Nok-1 
Table 1

Binding constants for the interaction of Flag-FasL and Flag-TRAIL with the Fc or COMP fusion protein of Fas and TRAIL-R2, respectively

\begin{tabular}{lcll}
\hline Receptor:chimera & $k_{\text {on }} \times 10^{4}\left(\mathrm{M}^{-1} \mathrm{~s}^{-1}\right)$ & $k_{\text {off }} \times 10^{-4}\left(\mathrm{~s}^{-1}\right)$ & $K_{\mathrm{D}}(\mathrm{nM})$ \\
\hline Fas:Fc & $3.4 \pm 0.84$ & $2.3 \pm 0.55$ & $6.7 \pm 1.4$ \\
Fas:Comp & $8.2 \pm 1.6$ & $0.63 \pm 0.12$ & $0.77 \pm 0.14$ \\
Trail-R2:Fc & $34.0 \pm 14$ & $1.4 \pm 0.43$ & $0.41 \pm 0.08$ \\
Trail-R2:Comp & $15.0 \pm 0.42$ & $1.0 \pm 0.28$ & $0.67 \pm 0.18$ \\
\hline
\end{tabular}

A

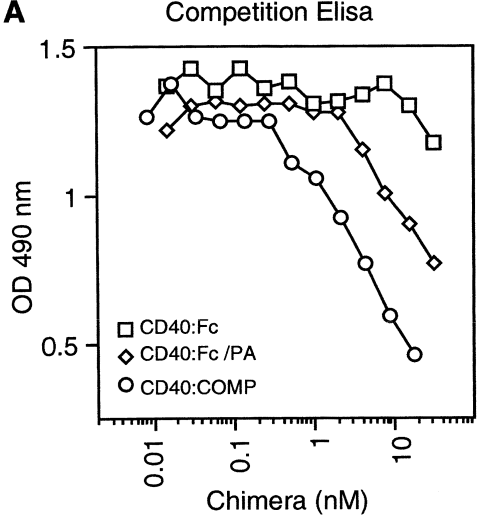

B

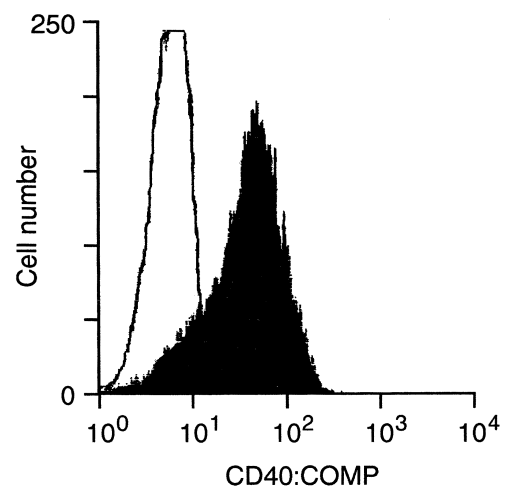

C

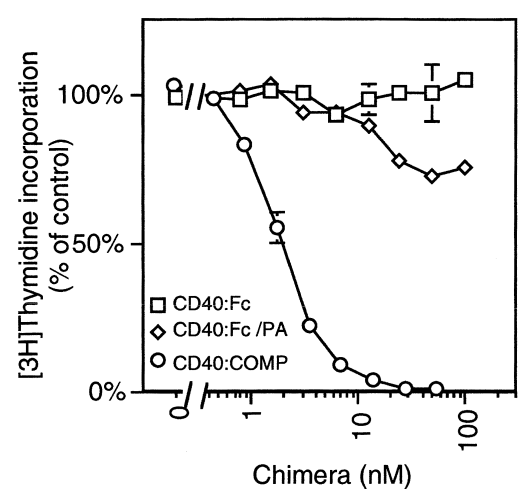

Fig. 5. CD40:COMP inhibits sCD40L. Panel A: Competition ELISA. CD40:Fc, CD40:Fc/PA or CD40:COMP were allowed to compete for sCD40L with coated CD40:Fc. Panel B: Staining of surface-expressed CD40L. The CD40L ${ }^{+}$Jurkat cell line D 1.1 was stained with either CD40:COMP or Fas:COMP as a control, and analyzed by FACS. Panel C: Inhibition of CD40L-dependent B-cell proliferation by CD40:COMP. CD19+ purified human PBLs were co-incubated with irradiated autologous CD19-PBLs and stimulated for $72 \mathrm{~h}$ with sCD40L in the presence of the indicated amounts of inhibitors. Results are expressed as percent of $\left[{ }^{3} \mathrm{H}\right]$-thymidine incorporation in the absence of inhibitors $\left(\left[{ }^{3} \mathrm{H}\right]\right.$-thymidine incorporation was $25000 \mathrm{cpm}$ in the absence of Protein A and $20000 \mathrm{cpm}$ in the presence of Protein A. Background incorporation was $700 \mathrm{cpm})$.

\section{Discussion}

Ligands of the TNF-family are trimeric and allow the binding of up to three receptors at their monomer-monomer boundaries (Banner et al., 1993). Recombinant dimeric receptors can therefore not fully exploit the avidity potential inherent in the structure of the ligands. Cross-linked ligands, which often display enhanced activity (Schneider et al., 1998), offer even more sites for high avidity receptor binding. We have constructed fusion proteins of various receptors to different dimeric ( $\partial \mathrm{N}-\mathrm{OPG})$,

Fig. 4. Binding of Fas to soluble and membrane-bound FasL is increased by oligomerization. Panel A: Competition ELISA. Soluble Fas:Fc, Fas:Fc/PA or Fas:COMP were allowed to compete with coated Fas:Fc for sFasL. Panels B and C: Titration of the inhibitory activity of Fas:Fc, Fas:Fc/PA and Fas:COMP. sFasL was used at concentrations of 0.9 nM (on Jurkat, BJAB and A20 cells) and 3.6 nM (on WEHI 164 cells). Panel D: The low activity of Fas:Fc on BJAB cells is not dependent on the Fc portion of the molecule. The experiment was performed as described in panel C, except that increasing amounts of TRAIL-R2:Fc (mock:Fc) were added. Panel E and F: Titration of the inhibitory activity of Fas chimeras and of the anti-FasL Nok-1 antibody. Jurkat cells were treated with sFasL at $7.2 \mathrm{nM}$ (eight-fold higher concentration than that used in panel B). Panel G: Fas:COMP protects primary mouse hepatocytes from FasL-induced death. Hepatocytes were cultivated in the presence of $7.2 \mathrm{nM}$ of sFasL. Panel H: Inhibition of activation-induced cell death (AICD) of Jurkat cells. Cells were exposed to coated anti-CD3 antibody in the presence of the indicated concentrations of Fas:Fc, Fas:Fc/PA and Fas:COMP. Protection is expressed as viability increase in the presence of inhibitors. In this model, up to $40 \%$ of cell death can be induced, about half of which can be inhibited with Fas:Fc/PA at saturating conditions (Kataoka et al., 1998). Panel I: Inhibition of FasL-dependent CTL activity by Fas:Fc or Fas:COMP. CTLs from perforin ${ }^{-1-}$ and $g l d$ mice were activated in a mixed lymphocyte culture (MLC) and cocultivated with [ $\left.{ }^{51} \mathrm{Cr}\right]-$ labeled A20 cells. $\left[{ }^{51} \mathrm{Cr}\right]$ release in the supernatant was quantified after $4 \mathrm{~h}$. 

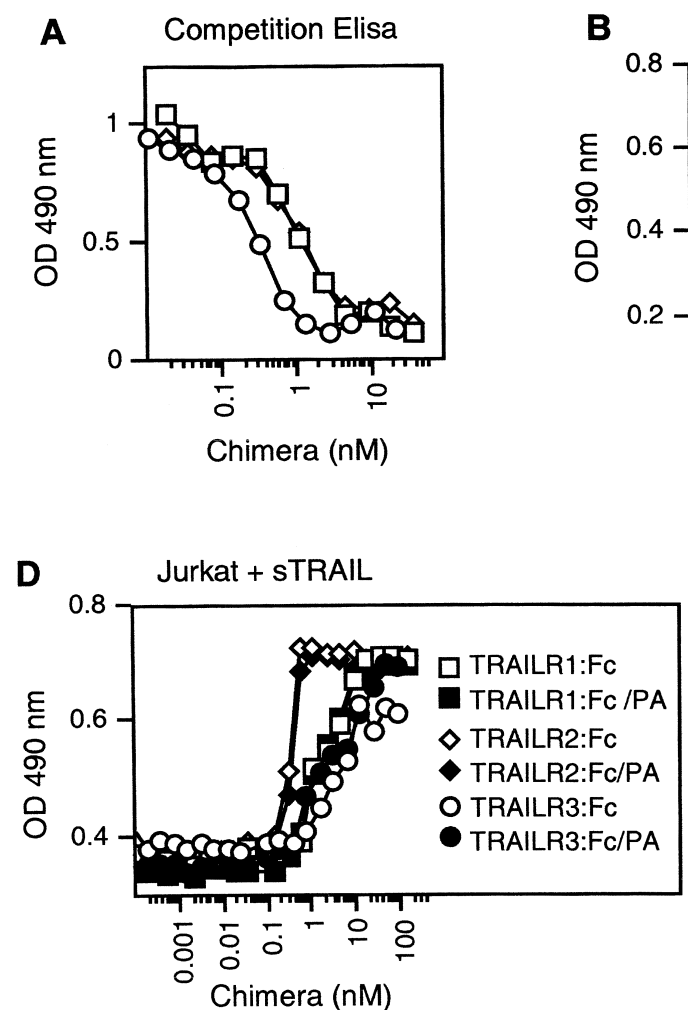
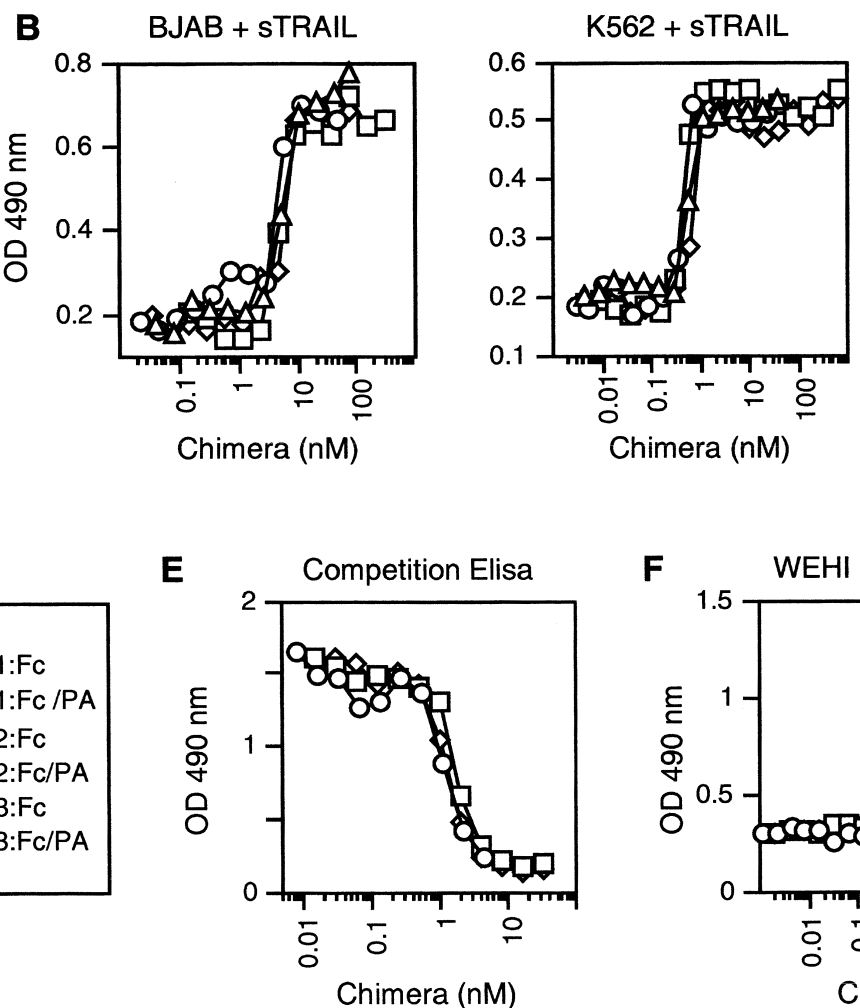

C Jurkat + sTRAIL

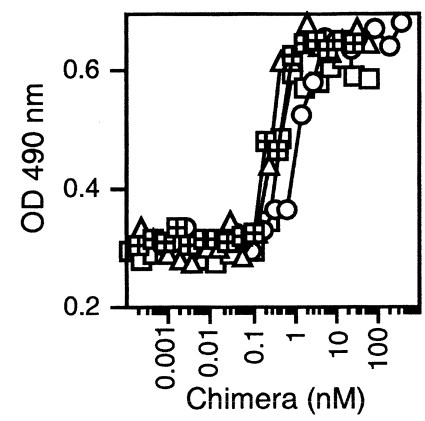

Fig 6. Binding of TRAIL-receptors and TNF-R1 to their respective ligands is not increased by oligomerization. Panel A: Competition ELISA Soluble TRAIL-R2.Fc, TRAIL-R2:Fc/PA or TRAIL-R2:COMP were allowed to compete for sTRAIL with coated TRAIL-R2:Fc. Panel B: Titration of the inhibitory activity of TRAIL-R2:Fc, TRAIL-R2:Fc/PA, TRAIL-R2:CMP and TRAIL-R2:COMP. sTRAIL was used at concentrations of $22 \mathrm{nM}$ (BJAB), $5.6 \mathrm{nM}$ (Jurkat) or 2.8 nM (K-562). Panel C: Titration of the inhibitory activity of TRAIL-R2 chimers. Jurkat cells were treated with sTRAIL at $2.8 \mathrm{nM}$. Panel D: The inhibitory activity of TRAIL-receptors:Fc is not increased by Protein A. Conditions were as described in panel C. Panel E: Competition ELISA. Soluble TNF-R1:Fc, TNF-R1:Fc/PA or TNF-R1:COMP were allowed to compete for sTNF $\alpha$ with coated TNF-R1:Fc. Panel F: Titration of the inhibitory activity of TNF-R1:Fc, TNF-R1:Fc/PA and TNF-R1:COMP. WEHI 164 cells were treated with sTNF $\alpha$ at 0.35 nM. 
trimeric (CMP), or pentameric (COMP) oligomerization supports and have compared them to receptor:Fc fusion proteins. Inhibition of sFasL-induced apoptosis by these competitive inhibitors increased as a function of their oligomerization level, and the relative activities of the various inhibitors (expressed as the ratio of their respective $\mathrm{IC}_{50}$ ) remained relatively constant when measured on several cell lines. The increased inhibitory efficiency of Fas:COMP as compared to Fas:Fc is the likely result of its higher avidity.

We identified three cases (BJAB, A20 cells and primary mouse hepatocytes) in which Fas:Fc largely or completely failed to block FasL for reasons that are unexplained. Under the same conditions, Fas:COMP efficiently blocked FasL, indicating that it is not only a more potent but also a more reliable inhibitor.

Fas:COMP was more efficient than Fas:Fc at blocking apoptosis mediated by membrane-bound FasL in a model of activation-induced cell death, but both reagents only partially blocked FasL-induced apoptosis mediated by CTLs. CTL action depends on both a close and tight contact with the target cell and on a transient and polarized activation of the cytotoxic machinery at the docking site (Bossi and Griffiths, 1999). Under these conditions, soluble receptors may be largely excluded from the cell to cell contact site, explaining their low activity. If this is true, oligomerized soluble Fas could selectively block soluble or ectopically expressed FasL without affecting the cytotoxic $\mathrm{T}$ cell response. This is of interest as ectopic expression of FasL has been reported to play a role in certain types of cancer and dermal diseases (Hahne et al., 1996; O'Connell et al., 1996; Strand et al., 1996; Viard et al., 1998).

Pentamerization not only increased the activity of Fas but also that of CD40. Indeed, CD40:COMP was far more potent than CD40:Fc to inhibit CD40Linduced proliferation of primary B-cells in vitro. However, pentamerization did not significantly improve the inhibitory activity of other receptors such as the TNF and TRAIL receptors. We observed that an increase in the affinity of a pentamerized receptor in the competition ELISA assay correlated with an improved inhibitory activity in biological assays. Therefore, pentamerization of receptors with relatively low affinity appears to be beneficial. This is consistent with the relatively high dissociation constant that we have measured between Fas:Fc and FasL $(7 \mathrm{nM})$ and that reported for CD40L and CD40:Fc (10-20 nM) (Hermann et al., 1993). By comparison, the KD between monomeric TNF-R1 and TNF $\alpha$ is as low as $0.59 \mathrm{nM}$ (Corti et al., 1994), and is close to $10 \mathrm{pM}$ for TNF $\alpha$ and TNF-R1 on cells at $37^{\circ} \mathrm{C}$ (Grell et al., 1998). Thus, binding of dimerized high affinity receptors to their ligands can probably be considered as nearly irreversible. Further aggregation of these receptors would therefore not result in a significant improvement of their inhibitory activities.

Our results show that dissociation constants in the lower nanomolar range can be obtained for those receptors such as Fas and CD40, which display intermediate affinity for their ligands, provided that they are multimerized. The affinities obtained are above those usually observed for monoclonal antibodies, and we could indeed show that Fas:COMP is an equally or more potent inhibitor of sFasL than NOK-1 and other widely used FasL-blocking antibodies.

\section{Acknowledgements}

This work was supported by grants of the Swiss National Science Foundation (to JT) and of the Swiss Federal Office of Public Health (to PS and JT). We thank Dr A. Terskikh (Stanford University, Stanford, CA) and Dr J.-P. Mach (Institute of Biochemistry, Epalinges, Switzerland) for providing rat COMP cDNA used in preliminary experiments, and Dr J. Browning (Biogen, Cambridge, MA) for the cDNAs of CD40 and CD40L. We are grateful to Dr D. Kroeger and Dr H. Vogel (Swiss Federal Institute of Technology, Lausanne, Switzerland) for their help with the BIAcore experiments. JR is supported by a Marie Heim Voegtlin subsidy.

\section{References}

Amakawa, R., Hakem, A., Kundig, T.M., Matsuyama, T., Simard, J.J., Timms, E. et al., 1996. Impaired negative selection of T cells in Hodgkin's disease antigen CD30-deficient mice. Cell 84, 551. 
Anderson, D.M., Maraskovsky, E., Billingsley, W.L., Dougall, W.C., Tometsko, M.E., Roux, E.R. et al., 1997. A homologue of the TNF receptor and its ligand enhance T-cell growth and dendritic-cell function. Nature 390, 175.

Bachmann, M.F., Wong, B.R., Josien, R., Steinman, R.M., Oxenius, A., Choi, Y., 1999. TRANCE, a tumor necrosis factor family member critical for CD40 ligand-independent $\mathrm{T}$ helper cell activation. J. Exp. Med. 189, 1025.

Banner, D.W., D'Arcy, A., Janes, W., Gentz, R., Schoenfeld, H.J., Broger, C. et al., 1993. Crystal structure of the soluble human 55-kd TNF receptor-human TNF beta complex: implications for TNF receptor activation. Cell 73, 431.

Bossi, G., Griffiths, G.M., 1999. Degranulation plays an essential part in regulating cell surface expression of Fas ligand in $\mathrm{T}$ cells and natural killer cells. Nat. Med. 5, 90.

Braun, M.Y., Lowin, B., French, L., Acha-Orbea, H., Tschopp, J., 1996. Cytotoxic T cells deficient in both functional Fas ligand and perforin show residual cytolytic activity yet lose their capacity to induce lethal acute graft-versus-host disease. J. Exp. Med. 183, 657.

Bucay, N., Sarosi, I., Dunstan, C.R., Morony, S., Tarpley, J., Capparelli, C. et al., 1998. Osteoprotegerin-deficient mice develop early onset osteoporosis and arterial calcification. Genes Dev. 12, 1260.

Campbell, K.A., Ovendale, P.J., Kennedy, M.K., Fanslow, W.C., Reed, S.G., Maliszewski, C.R., 1996. CD40 ligand is required for protective cell-mediated immunity to Leishmania major. Immunity 4, 283.

Chamow, S.M., Ashkenazi, A., 1996. Immunoadhesins: principles and applications. Trends Biotechnol. 14, 52.

Corti, A., Poiesi, C., Merli, S., Cassani, G., 1994. Tumor necrosis factor (TNF) alpha quantification by ELISA and bioassay: effects of TNF alpha-soluble TNF receptor (p55) complex dissociation during assay incubations. J. Immunol. Meth. 177, 191.

Dhein, J., Walczak, H., Baumler, C., Debatin, K.M., Krammer, P.H., 1995. Autocrine T-cell suicide mediated by APO-1/(Fas/ CD95). Nature 373, 438-441.

Ettinger, R., Browning, J.L., Michie, S.A., van Ewijk, W., McDevitt, H.O., 1996. Disrupted splenic architecture, but normal lymph node development in mice expressing a soluble lymphotoxin-beta receptor-IgG1 fusion protein. Proc Natl Acad Sci USA 93, 13102.

Grell, M., Wajant, H., Zimmermann, G., Scheurich, P., 1998. The type 1 receptor (CD120a) is the high-affinity receptor for soluble tumor necrosis factor. Proc. Natl. Acad. Sci. USA 95, 570.

Grewal, I.S., Xu, J., Flavell, R.A., 1995. Impairment of antigenspecific T-cell priming in mice lacking CD40 ligand. Nature $378,617$.

Griffith, T.S., Wiley, S.R., Kubin, M.Z., Sedger, L.M., Maliszewski, C.R., Fanger, N.A., 1999. Monocyte-mediated tumoricidal activity via the tumor necrosis factor- related cytokine, TRAIL. J. Exp. Med. 189, 1343.

Hahne, M., Rimoldi, D., Schroter, M., Romero, P., Schreier, M., French, L.E. et al., 1996. Melanoma cell expression of Fas(Apo-1/CD95) ligand: implications for tumor immune escape. Science 274, 1363.
Hanabuchi, S., Koyanagi, M., Kawasaki, A., Shinohara, N., Matsuzawa, A., Nishimura, Y. et al., 1994. Fas and its ligand in a general mechanism of T-cell-mediated cytotoxicity. Proc. Natl. Acad. Sci. USA 91, 4930.

Hauser, N., Paulsson, M., 1994. Native cartilage matrix protein (CMP). A compact trimer of subunits assembled via a coiledcoil alpha-helix. J. Biol. Chem. 269, 25747.

Hermann, P., Blanchard, D., de Saint-Vis, B., Fossiez, F., Gaillard, C., Vanbervliet, B. et al., 1993. Expression of a 32-kDa ligand for the CD40 antigen on activated human T lymphocytes. Eur. J. Immunol. 23, 961.

Ju, S.T., Panka, D.J., Cui, H., Ettinger, R., el-Khatib, M., Sherr, D.H. et al., 1995. Fas(CD95)/FasL interactions required for programmed cell death after T-cell activation. Nature 373, 444.

Kataoka, T., Schroter, M., Hahne, M., Schneider, P., Irmler, M., Thome, M. et al., 1998. FLIP prevents apoptosis induced by death receptors but not by perforin/granzyme B, chemotherapeutic drugs, and gamma irradiation. J. Immunol. 161, 3936.

Kayagaki, N., Kawasaki, A., Ebata, T., Ohmoto, H., Ikeda, S., Inoue, S. et al., 1995. Metalloproteinase-mediated release of human Fas ligand. J. Exp. Med. 182, 1777.

Kayagaki, N., Yamaguchi, N., Nakayama, M., Eto, H., Okumura, K., Yagita, H., 1999. Type I interferons (IFNs) regulate tumor necrosis factor-related apoptosis-inducing ligand (TRAIL) expression on human $\mathrm{T}$ cells: A novel mechanism for the antitumor effects of type I IFNs. J. Exp. Med. 189, 1451.

Lacey, D.L., Timms, E., Tan, H.L., Kelley, M.J., Dunstan, C.R., Burgess, T. et al., 1998. Osteoprotegerin ligand is a cytokine that regulates osteoclast differentiation and activation. Cell 93, 165

Laman, J.D., Claassen, E., Noelle, R.J., 1996. Functions of CD40 and its ligand, gp39 (CD40L). Crit. Rev. Immunol. 16, 59.

Malashkevich, V.N., Kammerer, R.A., Efimov, V.P., Schulthess, T., Engel, J., 1996. The crystal structure of a five-stranded coiled coil in COMP: a prototype ion channel? Science 274, 761.

Nocentini, G., Giunchi, L., Ronchetti, S., Krausz, L.T., Bartoli, A., Moraca, R. et al., 1997. A new member of the tumor necrosis factor/nerve growth factor receptor family inhibits $T$ cell receptor-induced apoptosis. Proc. Natl. Acad. Sci. USA 94, 6216.

O’Connell, J., O’Sullivan, G.C., Collins, J.K., Shanahan, F., 1996. The Fas counter-attack: Fas-mediated T cell killing by colon cancer cells expressing Fas ligand. J. Exp. Med. 184, 1075.

Russell, J.H., Rush, B., Weaver, C., Wang, R., 1993. Mature T cells of autoimmune $1 \mathrm{pr} / \mathrm{lpr}$ mice have a defect in antigenstimulated suicide. Proc. Natl. Acad. Sci. USA 90, 4409.

Schneider, P., Bodmer, J.L., Holler, N., Mattmann, C., Scuderi, P., Terskikh, A. et al., 1997. Characterization of Fas (Apo-1, CD95)-Fas ligand interaction. J. Biol. Chem. 272, 18827.

Schneider, P., Holler, N., Bodmer, J.L., Hahne, M., Frei, K., Fontana, A., Tschopp, J., 1998. Conversion of membranebound Fas(CD95) ligand to its soluble form is associated with downregulation of its proapoptotic activity and loss of liver toxicity. J. Exp. Med. 187, 1205.

Simonet, W.S., Lacey, D.L., Dunstan, C.R., Kelley, M., Chang, M.S., Luthy, R. et al., 1997. Osteoprotegerin: a novel secreted 
protein involved in the regulation of bone density. Cell 89, 309.

Stack, W.A., Mann, S.D., Roy, A.J., Heath, P., Sopwith, M., Freeman, J. et al., 1997. Randomised controlled trial of CDP571 antibody to tumour necrosis factor-alpha in Crohn's disease. Lancet 349, 521.

Strand, S., Hofmann, W.J., Hug, H., Muller, M., Otto, G., Strand, D. et al., 1996. Lymphocyte apoptosis induced by CD95 (APO-1/Fas) ligand-expressing tumor cells — a mechanism of immune evasion? Nat. Med. 2, 1361-1366.

Suda, T., Takahashi, T., Golstein, P., Nagata, S., 1993. Molecular cloning and expression of the Fas ligand, a novel member of the tumor necrosis factor family. Cell 75, 1169.

Tanaka, M., Suda, T., Haze, K., Nakamura, N., Sato, K., Kimura, F. et al., 1996. Fas ligand in human serum. Nat. Med. 2, 317.

Terskikh, A.V., Le Doussal, J.M., Crameri, R., Fisch, I., Mach, J.P., Kajava, A.V., 1997. 'Peptabody': a new type of high avidity binding protein. Proc. Natl. Acad. Sci. USA 94, 1663.

Thome, M., Schneider, P., Hofmann, K., Fickenscher, H., Meinl, E., Neipel, F. et al., 1997. Viral FLICE-inhibitory proteins (FLIPs) prevent apoptosis induced by death receptors. Nature 386, 517.

van Kooten, C., Banchereau, J., 1997. Functions of CD40 on B cells, dendritic cells and other cells. Curr. Opin. Immunol. 9, 330.

Vassalli, P., 1992. The pathophysiology of tumor necrosis factors. Ann. Rev. Immunol. 10, 411.
Viard, I., Wehrli, P., Bullani, R., Schneider, P., Holler, N., Salomon, D. et al., 1998. Inhibition of toxic epidermal necrolysis by blockade of CD95 with human intravenous immunoglobulin. Science 282, 490.

Weinblatt, M.E., Kremer, J.M., Bankhurst, A.D., Bulpitt, K.J., Fleischmann, R.M., Fox, R.I. et al., 1999. A trial of etanercept, a recombinant tumor necrosis factor receptor:Fc fusion protein, in patients with rheumatoid arthritis receiving methotrexate. N. Engl. J. Med. 340, 253.

Wiltscheck, R., Kammerer, R.A., Dames, S.A., Schulthess, T., Blommers, M.J., Engel, J. et al., 1997. Heteronuclear NMR assignments and secondary structure of the coiled coil trimerization domain from cartilage matrix protein in oxidized and reduced forms. Protein Sci. 6, 1734.

Wong, B.R., Josien, R., Lee, S.Y., Sauter, B., Li, H.L., Steinman, R.M. et al., 1997. TRANCE (tumor necrosis factor [TNF]related activation-induced cytokine), a new TNF family member predominantly expressed in $\mathrm{T}$ cells, is a dendritic cell-specific survival factor. J. Exp. Med. 186, 2075.

Yamaguchi, K., Kinosaki, M., Goto, M., Kobayashi, F., Tsuda, E., Morinaga, T. et al., 1998. Characterization of structural domains of human osteoclastogenesis inhibitory factor. J. Biol. Chem. 273, 5117.

Zheng, L., Fisher, G., Miller, R.E., Peschon, J., Lynch, D.H., Lenardo, M.J., 1995. Induction of apoptosis in mature T cells by tumour necrosis factor. Nature 377, 348 . 